\title{
Evropský veřejný ochránce práv
}

\author{
Štěpán Kořínek * \\ DOI: https://doi.org/10.24040/sap.2021.8.4.303-320
}

\begin{abstract}
Abstrakt:
KOŘÍNEK, Štěpán: Evropský veřejný ochránce práv. Instituce Evropského veřejného ochránce práv je pevně etablovaný mechanismus vnější kontroly unijní administrativní mašinérie. Evropský ombudsman plní svojí misi již téměř tř̌i dekády, i přesto se však zdá, že jeho existence je poněkud upozaděna. Respektive se o něm, jakožto o zažité entitě vůbec nebo jen málo hovoří. Evropský integrační proces má neustále tendence $\mathrm{k}$ intenzifikaci, což s sebou přináší i kvantifikaci institucionálního aparátu - unijní administrativy. Každá nová instituce či orgán EU však zároveň navyšuje potencionální riziko nevhodné správní praxe, která se nejčastěji projevuje jako nesprávný úřední postup. Tento príspěvek si klade za cíl připomenout a přiblížit institucionální existenci a činnost evropského ombudsmana. In concreto má ambice přinést vyšší míru povědomí o funkcionalitě evropského ombudsmana. Př́spěvek je systematicky rozdělen do třech hlavních částí. První část se věnuje základní charakteristice evropského ombudsmana z hlediska jeho právního základu, struktury, pravomocí a činnosti. Druhá část prrináší historické okénko cesty vzniku konceptu ombudsmanství, s pozorností na zrod Evropského ombudsmana. Třetí část se zabývá komplikacemi jeho činnosti, zejména s ohledem na potřebu zvyšování transparentnosti a dostupnosti.
\end{abstract}

\section{Klíčová slova:}

lidská práva a svobody, ochrana lidských práv, evropský ochránce práv, ombudsman, Evropská unie

\section{The European Ombudsman}

\begin{abstract}
:
KOŘÍNEK, Štěpán: The European Ombudsman. The European Ombudsman is a firmly established mechanism of an external control of the EU administration. The European Ombudsman is fulfilling its mission almost for three decades despite of its invisibility. Respectively, there is not a discussion about him because of its a long term existence. The european integration process has a constant tendency to the intensification which brings a quantification of the institutional apparatus - administrative of the EU. Simultaneously, every new institution or body of the EU is increasing a potential risk of improper administration also known as maladministration. This contribution aims to remind and to approximate the institutional existence and activity of the European Ombudsman. In concreto it has an ambition to bring a greater degree of awareness about a functionality of
\end{abstract}

* JUDr. Bc. Štěpán Kořínek. Právnická fakulta Univerzity Karlovy v Praze; skorinek@seznam. cz / gmkorinek@gmail.com. 
the European Ombudsman. The contribtuion is systematically devided into three main parts. The first part is devoted to the basic characteristics of the European Ombudsman in terms of its legal basis, structure, competences and activity. The second part brings a historical review of the road of ombudsmania with an attention to the origin of the European Ombudsman. The third section deals with the complications of its activity in particular with regard to the requirement of increasing of transparency and availability.

\section{Key words:}

Human Rights and Freedoms, Protection of Human Rights, European Ombudsman, Ombudsman, European Union

\section{Úvod}

„My ambition is to support the EU institutions in becoming more effective, transparent and accountable by strategically increasing the visibility and impact of the work of the European Ombudsman." Emily O'Reilly v roce 2014

Tento př́spěvek si klade za cíl príblížit, tedy vlastně zosobnit, instituci Evropského veřejného ochránce práv alias Evropského ombudsmana (dále jako „EO“), který je součástí evropského právního řádu od roku 1992, kdy vstoupila v platnost Maastrichtská smlouva. Dnes se již jedná o pevně zakořeněný organismus, který má však značně nevýhodné postavení a velmi nesnadnou misi. Evropský ombudsman zcela jednoznačně kvalitativně doplňuje proces evropské integrace. Jeho připisovatelnou výhodou zůstává snižování demokratického deficitu a tím vlastně zvyšování demokratičnosti Evropské unie (dále jen „EU“). ${ }^{1}$ To se děje na základě konceptu tzv. democratic empowerment, což lze volně přeložit jako demokratické zplnozmocnění. ${ }^{2}$ Celý koncept přitom vychází $\mathrm{z}$ ideji rozšiřování lidskoprávních standardů $\mathrm{v} E U$ stále více a více směrem $\mathrm{k}$ občanům. Díky tomu je pak zajištěna občanům $\mathrm{EU}^{3}$ větši míra participace na tvorbě a činnosti evropské politiky. Instituce Evropského veřejného ochránce práv může být také vnímána jako konstitucionální koncept nezávislé a dostupné „soft-kontroly“ veřejné správy (někdy bývá označována jako jistá forma supervize), která má úzký vztah k principům a východiskům demokratického právního státu. ${ }^{4}$

1 MOURE-PINO, A. M. The European Ombudsman in the framework of the European Union. In Revista Chilena de Derrecho, 2011, roč. 38, č. 3, s. 433.

2 LEVI-FAUR, D. - KOSTI, N. - WAARDEN, V. F. Democratic empowerment in the European Union: an introduction. In LEVI-FAUR, D. - WAARDEN, V. F. Democratic empowerment in the European Union. Cheltenham, UK - Northampton, MA - USA: Edward Elgar Publishing, 2018, s. 1.

3 Občanství EU není svébytná kategorie, nýbrž pouhá komplementarita k národnímu občanství každé osoby, která má úzký občanský vztah k členskému státu EU. Evropské občanství proto nemůže existovat bez občanství k některému členskému státu EU. Charakter občanství EU je akcesorický, tedy doplňující a nenahrazující.

4 PLÍVOVÁ, P. Český a evropský ombudsman jako ochránci pred zakázanou diskriminací. Diplomová práce. Pardubice : Fakulta ekonomicko-správní UPCE, 2011, s. 10. 
Evropská unie jako supranacionální útvar sui generis jest založena na přenosu pravomocí z členských států. Prvek konjunkce členských států však nedosahuje takového intenzity, aby se dalo hovořit o vzniku federálního soustátí. Členské státy nedosahují společné vůle $\mathrm{k}$ úplnému podřízení se nadnárodnímu útvaru. To je důvodem toho, že zůstávají v postavení originárních nositelů pravomocí a kompetencí, které pouze propůjčují, přesněji přenášejí, $v$ předem stanoveném rozsahu. ${ }^{5}$ Následná dělba pravomocí je však z dnešního sociologicko-politického hlediska vývoje značně kontroverzní. Přenos a dělba pravomocí je jedním ze základních nosných kamenů konceptu „democratic empowerment", nebot' se v nich odráží společenská vůle občanů členských států. Občané EU se podílejí na tvorbě evropské politiky skrze své politické zástupce, avšak primárním nositelem veškeré moci a vůle jsou právě občané členských států, kteří mohou často tuto vůli i projevit (referendum).

Co přesně skrývá používaný koncept „,democratic empowerment"? Opět se setkáváme s nejednoznačností a vyčerpatelnou nedefinovatelností, nebot’ tento zastřešující koncept nemůže být uspokojivě a zcela jasně definován. Jeho podstata sestává z několika dílčích podkonceptů a aspektů, zejména z evropského občanství, demokratičnosti a politické participace na evropské nadnárodní scéně. Některé práce hovoří o klíčové dimenzi označující kvalitu a úroveň institucionalizace demokracie. ${ }^{6}$ Demokracie je mnohovýznamový pojem, který je od svých raných dob považována za vládu všech, respektive za vládu, na které se podílejí všichni členové společnosti. Logicky vzato, aby mohla úspěšně fungovat, musí být založena na moci a vůli lidu. Občané vytvářejí vládu a institucionální rámec, který právě přivádí v život oním demokratickým zplnozmocněním. Respektive, udělují vybraným jedincům a institucím zastoupení pro společenskou správu a ř́zení.

Občanství EU bylo jako další prvek evropské integrace zavedeno také v roce 1992 na základě Maastrichtské smlouvy, stejně jako Evropský ombudsman. Občanství EU má prozatím benefitní povahu, protože na sebe váže značné množství práv, kterým je potřeba věnovat náležitou pozornost, zejména $\mathrm{z}$ hlediska jejich ochrany. ${ }^{7} \mathrm{Na}$ druhé straně, smluvní rámec však nevylučuje i zatížení povinnostmi (např́klad branná povinnost). ${ }^{8}$ Analogicky vzato, patří ochrana lidských práv v EU také k základním cílům a hodnotám. ${ }^{9}$ Jedná se zajisté o nelehký úkol, nebot škála lidských práv a svobod je značně rozsáhlá a neustále se objevují nové a nové hrozby. Na druhou stranu však paralelně narůstá i katalog lidských práv, a to zejména díky moderním vývojovým

5 TOMÁŠEK, M. a kol. Právo Evropské unie. Praha : Leges, 2013, s. 147.

6 LEVI-FAUR, D. - KOSTI, N. - WAARDEN, V. F. Democratic empowerment in the European Union: an introduction. In LEVI-FAUR, D. - WAARDEN, V. F. Democratic empowerment in the European Union. Cheltenham, UK - Northampton, MA - USA : Edward Elgar Publishing, 2018, s. 1.

7 ŠABATOVÁ, A. - KŘEČEK, S. a kol. Občanství Evropské unie. Brno : Kancelář veřejného ochránce práv, 2017, s. 27 an.

8 SIMAN, M. - SLAŠŤAN, M. Právo Európskej únie. Bratislava : EUROIURIS, 2012, s. 72.

9 Čl. 3 SEU. Mezi politické cíle EU patří definování a dodržování základních hodnot a demokratických zásad EU, vytvoření a respektování občanství EU. Čl. 2 SEU potom uvádí hodnoty EU, pro nás důležitých zejména demokracie, rovnost, právní stát a respektování lidských práv. 
trendům. Legislativní rámec pro ochranu lidských práv je v evropském prostoru také členitý. Nutno mít na paměti, že EU je jen posledním evolutivním krokem v tomto směru, již dříve se konstituovaly specifické orgány a instituce, které se orientovaly na ochranu lidských práv. Instituci evropského ombudsmana je v tomto ohledu možno označit za pružnou, nebot' prríhodně vyvažuje turbolentnost vývoje administrativy EU. ${ }^{10}$ Nejvýznamnější z nich, Rada Evropy a k ní přidružený Evropský soud pro lidská práva (dále jen „ESLP“) jsou zářným př́íkladem projevení snah o zintenzivnění ochrany lidských práv v historickém kontextu. Status občanství EU tak umožňuje každému občanu členského státu EU obracet se (podávat stížnost k) na Evropského veřejného ochránce práv v souvislosti s nesprávným úředním postupem instituce či orgánu EU. ${ }^{11}$

\section{Evropský veřejný ochránce práv - základní charakteristika}

Instituce Evropského veřejného ochránce práv neboli Evropského ombudsmana je považován za svébytný orgán sui generis. Z jeho ustálené povahy vyplývá, že není považován za strukturální agenturu EU, nebot' mu je vytýkán nedostatek regulativnosti a výkonné moci. ${ }^{12}$ Vedle toho, vyniká kvalitativními znaky specifického postavení jako nestrannosti a nezávislosti na unijních strukturách. Ve své podstatě se jedná o nástroj politické intervence evropských občanů na základě demokratického plnozmocnění. Respektive, jeho zavedením se kvalitativně zvyšuje demokratické zázemí EU, což v konečném důsledku přispívá k snižování demokratického deficitu EU a prohloubení integrace. Status evropského ombudsmana je takový, že se jedná o nezávislou a nestrannou entitu s potenciálem silného vlivu na zbylé unijní instituce a politické sféry. Evropský ombudsman má sloužit demokracii spoluprací (usměrňování činnosti) unijních institucí a orgánů za sledování cíle vytvoření více efektivní, odpovědné, transparentní a etické administrativy EU. ${ }^{13}$ Kreace instituce Evropského ombudsmana byla podmíněna několika dílčími faktory. Obecně lze vymezit požadavek jeho separace od konsolidované supranacionální dynamiky EU. Evropský ochránce práv byl zaveden Maastrichtskou smlouvou v roce, při požadavcích na odbourání několika dílčích nedokonalostí EU. Prima facie k jeho zavedení byla požadována na základě požadavků k zvýšení institucionální odpovědnosti struktur EU, dále k posílené transparentnosti EU, ke snižování evergreenu demokratického deficitu, k minimalizaci byrokratické a technokratické povahy EU a v neposlední řadě k vyjasnění a upřesnění stinného vykládání evropských norem. ${ }^{14}$

10 TRONDEL, J. - WILLE, A. The European Ombudsman: a resilient institution in a turbolent, evolving administration order. In HOFMANN, H. C. H. - ZILLER, J. Accountability in the EU: the role of the European Ombudsman. Cheltenham : Edward Elgar Publishing, 2017, s. 28-58.

11 Čl. 24 SFEU: „Každý občan Unie se může obracet na veřejného ochránce práv ustanoveného v souladu s článkem 228 .“

12 INGLESE, M. - BINDER, T. The European Ombudsman. In LEVI-FAUR, D. - WAARDEN, V. F. Democratic empowerment in the European Union. Cheltenham, UK - Northampton, MA - USA : Edward Elgar Publishing, 2018, s. 85.

13 CRAIG, P. EU administrative law. Oxford : Oxford University Press, 2018, s. 795-798.

14 INGLESE, M. - BINDER, T. The European Ombudsman. In LEVI-FAUR, D. - WAARDEN, V. F. Democratic empowerment in the European Union. Cheltenham, UK - Northampton, MA - USA : Edward Elgar Publishing, 2018, s. 85. 
Evropský ombudsman má unikátní postavení, což pramení i ze skutečnosti toho, že absentuje jeho formální legislativní vymezení jako takové. Navíc, toto unikum je podtrhnuto i podivnou metapozicí v rámci tzv. trias politicas, neboli pomezí trojí moci - normotvorné, exekutivní a soudní. Evropský ombudsman je volen Evropským parlamentem (dále jen „EP“), kde se projevuje normotvorná moc. Zároveň je oprávněn řešit nesprávný úřední postup unijních orgánů a institucí, čímž zasahuje do jejich exekutivní moci. ${ }^{15}$ Posléze je úzce navázán i na soudní moc, zejména tím, že skládá přísahu do rukou Soudního dvora EU a může být i z jeho vůle propuštěn. Tato triáda průniku jednotlivých mocí je jeho identifikačním znakem. EO tak vlastně vyplňuje mezeru mezi zákonodárnou a výkonnou mocí EU. ${ }^{16}$ Evropský ochránce práv však nemůže zasahovat do výkonu soudní moci, respektive do výkonu soudních pravomocí Soudního dvora EU, čímž dochází k respektu dělby moci. Institucionální rovnováha EU je přitom nesmírně důležitá, nebot' jí je nutné vnímat jako funkční ekvivalent klasické dělby moci ve státních útvarech. Ve vztahu k unijní soudní moci je ještě významné, že EO se úspěšně angažuje v mimosoudní proceduře vyjednávání (mediaci) řešení správních konfliktů. ${ }^{17}$

Právní základ Evropského veřejného ochránce práv se nachází v primárním právu EU, přesněji v textu Smlouvy o fungování Evropské unie (dále jen „SFEU“). Evropský ombudsman není v rámci těchto ustanovení konkrétně definován. Př́́slušné ustanovení pouze stanovuje jeho pravomoci a vymezuje úkoly. ${ }^{18}$ Ústřední činnost ombudsmana obecně rotuje kolem zajištění vyšší míry efektivnosti státní správy, která často skýtá mnohé nedostatky a negativa. Jinými slovy by se dalo vyjádřit, že ombudsman má především přispívat ke zkvalitňování administrativy, čímž se vyznačuje funkcí zkvalitnění. ${ }^{19}$ Ombudsman tak působí prvořadě jako služba pro zisk zpětné vazby pro zajištění lepší, kvalitnější a výkonnější administrativy. ${ }^{20}$ Vedle toho je elementárním pramenem i Statut

15 MORRISSEY, C. EU accused of 'maladministration' on Mercosur deal by Ombudsman. In Irish Farmers Journal [online]. Zveřejněno dne: 20. 03. 2021. Dostupné z: https://www. farmersjournal.ie/eu-accused-of-maladministration-on-mercosur-deal-by-ombudsman-610282.

16 GOBBI, M. The European Ombudsman: a modern Defensor Civitatis of EU citizens. In Academia [online]. Dostupné z: https://www.academia.edu/2246611/The_European_ Ombudsman_a_modern_Defensor_Civitatis_of_EU_citizens_M_Gobbi_en_.

17 BATALLI, M. Role of Ombudsman Institution Over the Administration. In Academic Journal of Business, Administration, Law and Social Sciences, 2015, roč. 1, č. 3, s. 232.

18 Čl. 228 SFEU: „Evropský veřejný ochránce práv volený Evropským parlamentem je oprávněn prijimat stižnosti od kteréhokoli občana Unie nebo od kterékoli fyzické osoby s bydlištěm nebo právnické osoby se statutárním sídlem v členském státě, které se týkaji prípadi̊ nesprávného úředniho postupu orgánů, institucí nebo jiných subjektů Unie, s výjimkou Soudního dvora Evropské unie při výkonu jeho soudních pravomocí. Stizznosti prezkoumává a podává o nich zprávu.“

19 MOURE-PINO, A. M. The European Ombudsman in the framework of the European Union. In Revista Chilena de Derrecho, 2011, roč. 38, č. 3, s. 433.

20 Emily O'Reilly: „What sets a good workplace apart is whether it has a culture of zero tolerance towards harassment and whether staff are informed about their rights and are empowered to act." BANKS, M. EU Ombudsman creates 'good practices' list to combat harassment. In The Parliament Magazine [online]. Zveřejněno dne: 02. 01. 2019. Dostupné z: https://www. theparliamentmagazine.eu/news/article/eu-ombudsman-creates-good-practices-list-to-combatharassment. 
evropského ombudsmana. ${ }^{21}$ Moderní nastavení ombudsmanství skýtá dva vzájemně závislé trendy. Prvním z nich je působení proti značné kvantifikaci administrativní správy a zátěže. V posledních dekádách jsme svědky extenzivní delegace moci a pravomocí na administrativní autority, tedy všemožné decentralizační snahy. Druhé směřování potom plní požadavek po navyšování a intenzifikaci poptávky po individuální ochraně práv a svobod. ${ }^{22}$ Obecně lze vyjádřit, že tato instituce vyplňuje mezeru mezi evropskými občany a byrokratickou administrativou EU, čímž tuto správu humanizuje. Celý proud potom přispívá k uplatňování principu dobré správy i na úrovni EU.

Kancelář evropského ombudsmana je monokraticky personalizována, což značí stav, kdy je moc svěřena do rukou jedné osoby. ${ }^{23}$ Samozřejmě, není reálné si vůbec představit, jakou neskutečnou zátěž taková funkce představuje. Národní ochránci práv bývají ze svého postu značně vytížení, přičemž jejich působnost je vždy omezena na konkrétní stát. Jen těžce si lze představit, jaká zátěž musí spočívat na bedrech osoby evropského ombudsmana, který představuje generálního ochránce lidských práv pro téměř třicet evropských státností. Je proto nasnadě spíše hovořit o kanceláři (potažmo „úřadu“" $)^{24}$ Evropského ombudsmana, protože ten musí mít kolem sebe rozsáhlý personální substrát odpovídající kvalifikačním kompetencím a požadavkům na dané pozice, aby byl zajištěn, pokud možno hladký chod a výkon jeho činnosti. Evropský ombudsman jako samostatná osoba se jeví spíše jako reprezentant Úřadu/Kanceláře, který má však jediné rozhodné slovo. V současné době pozici Evropského ochránce práv zastává Emily O’Reilly, ${ }^{25}$ která do své funkce nastoupila v roce 2013. Paní O’Reilly je teprve třetí osobou v pozici Evropského ochránce práv, z čehož plyne, že výkon mandátu Evropského ombudsmana se nese v delších časových intervalech. ${ }^{26}$

Evropský ochránce práv disponuje spektrem specifických pravomocí, které jsou typické jeho statusu a činnosti. Na prvním místě můžeme hovořit o jeho vyšetřovací

21 Rozhodnutí Evropského parlamentu o pravidlech a obecných podmínkách pro výkon funkce veřejného ochránce práv ze dne 09. 03. 1994, ve znění příslušných změn.

22 INGLESE, M. - BINDER, T. The European Ombudsman. In LEVI-FAUR, D. - WAARDEN, V. F. Democratic empowerment in the European Union. Cheltenham, UK - Northampton, MA - USA: Edward Elgar Publishing, 2018, s. 87.

23 KUCSKO-STANDLMAYER, G. (ed.). European Ombudsman-Institutions. Vienna : Springer, 2008, s. 171 an.

24 Pojem „úřad“ je v této souvislosti spojen s významem celé organizační struktury instituce evropského ombudsmana, přičemž nemá evokovat představy o tom, že by tato instituce byla nedílnou součástí autoritativní unijní moci. Pojem ,úurăa“ je tak vnímán a používán výlučně pro účely tohoto prríspěvku, a to jako vhodná zkratka subsumující instituci (kancelář) evropského ombudsmana $\mathrm{v}$ její celistvosti.

25 Emily O’Reilly je bývalá irská žurnalistka, která se v roce 2003 stala vůbec první ženou v pozici veřejného ochránce práv v Irsku a od roku 2007 i komisařkou pro informace týkajícího se životního prostředí. Současná evropská ombudsmanka byla několikrát oceněna žurnalistickými cenami, ale i honorovanými akademickými tituly.

26 První evropský ochránce práv byl dosazen v roce 1995 a stal se jím Jacob Söderman z Finska, který pozici zastával od roku 1995 do 2003. Druhým evropským ombudsmanem se stal P. Nikiforos Diamandouros z Řecka, který funkci vykonával do roku 2013. Následně byla do Úřadu zvolena Emily O’Reilly, která tuto funkci vykonává dodnes. 
pravomoci (investigate power). ${ }^{27}$ Proces vyšetřování může zahájit bud' na podnět legitimovaných subjektư ${ }^{28}$ nebo i z vlastní iniciativy ex officio. Dozví-li se o nějakém pochybení či nesprávném úředním postupu (maladministration) ${ }^{29}$ unijních institucí, které mělo potenciál ohrozit či narušit, nebo tak i učinilo, práv dotčených osob, zahájí kroky k náležitému objasnění všechny relevantních skutečností a odkrytí všech latentních okolností. Konkrétní pravomoc a působnost tak byla stanovena na nesprávný úřední postup, který se však může odrazit v administrativních nesrovnalostech a pochybeních, diskriminačním jednání, zneužití pravomocí, bezdůvodném neposkytnutí informací či neodůvodněných průtazích řízení. Za další pravomoc můžeme vyzdvihnout dotazovací (interrogation power), která přispívá k oné první, čímž také slouží k objasnění jakéhokoli podezrrelého nesprávného úředního postupu. Úřad je oprávněn zahájit konstruktivní dialog s dotčeným orgánem či institucí za sledování cíle eliminace jejich pochybení (nesprávný úřední postup) a přijmutí precizačního nápravného doporučení, jež dané instituci předloží. Dotčená instituce či orgán mají lhůtu třech měsíců k podání odpovědi na závěry Evropského ombudsmana. Tyto pravomoci bývají doplňovány o další, kterou je notifikační pravomoc (notification power), která skýtá dvě roviny úhlu pohledu. První zorné pole zachycuje povinnost poskytnutí potřebných a vyžádaných informací evropskému ombudsmanovi při výkonu jeho činnosti, kdežto druhý náhled představuje možnost žádat poskytnutí informací od jiných subjektů. Daná pravomoc má však širší konsekvence, nebot' z ní vyplývá i povinnost informovat Evropský parlament v případě nějakých zjištění. Konečně, i finální report z vyšetřování se vedle dotčené instituce, zasílá i Evropskému parlamentu. Vedle toho spadá do vymezených kompetencí i vyzývat k podání výpovědi či výslechu v případě svědčení v soukromoprávních otázkách dané kauzy, kde tento Úřad napomáhá hledání konstruktivního řešení. ${ }^{30}$

27 Čl. 228 SFEU: „V souladu se svými povinnostmi provádi veřejný ochránce práv šetření, která považuje za opodstatněná, a to z vlastniho podnětu nebo na základě stižnosti predložených mu přmo nebo prostřednictvím člena Evropského parlamentu, pokud tvrzené skutečnosti nejsou nebo nebyly predmětem soudniho ř́zeni. Jestliže veřejných ochránce práv zjistí nesprávný úredni postup, postoupi věc dotyčnému orgánu, instituci nebo jinému subjektu, který má lhůtu tři měsíců na to, aby mu sdělil své stanovisko. Poté předá Evropskému parlamentu a dotyčnému orgánu, instituci nebo jinému subjektu zprávu. Osobu podávajici stižnost informuje o výsledku tohoto šetřeni."“

28 Čl. 24 SFEU uvádí: „Každý občan Unie se může obracet na veřejného ochránce práv ustanoveného v souladu s článkem 228.“

29 Maladministration = lack of administration due to a situation when an authority does not operate according to the law, it does not respect the principles of good administration or it violates the human rights.

30 Evropský ombudsman má $\mathrm{k}$ dispozici pouze právně nezávazné nástroje, kterými jsou různá stanoviska, doporučení, zprávy atd. Za zmínku však stojí dva z nich, kterými jsou kritická poznámka a zvláštní zpráva. Kritickou poznámku může vydat v př́padě, že dotčená unijní instituce či orgán neodstraní zjištěné nedostatky. Kritická poznámka však zůstává preventivního charakteru spočívajícího ve faktickém upozornění na přetrvávající závadný stav. Vedle toho za nejsilnější nástroj se považuje tzv. zvláštní zpráva, kterou Evropský ombudsman předkládá Evropskému parlamentu. Obsahem zprávy je návrh na systematické řešení s př́padným předložením návrhu př́pustných nápravných opatření. Evropský parlament však může se zprávou libovolně naložit dle svého vlastního přesvědčení, tedy ani tento nástroj nedisponuje donucovací mocí. 
Pro účely zajištění vyšší efektivnosti a intenzivnější spolupráce se jednotliví národní ochránci práv seskupili do tzv. Evropské sítě veřejných ochránců práv (ombudsmanů), kde úspěšně participuje i Evropský ombudsman. Tato unikátní struktura vznikla roku 1996 na modelu horizontální spolupráce otevřeného fóra, kde dochází především k výměně informací, koordinaci a sdílení praktických zkušeností, potřebně podpoře a pomoci, rekvalifikačním nabídkám a podobným podpůrným aktivitám. Komplementární vlastnost takto navázané spolupráce také tkví v transferu stížností a spolupráci na jejich řešení. ${ }^{31}$ Klíčový prvek však zůstává imanentní, nebot' národní ombudsmani jsou takto zahrnuti do dílčího rozhodovacího procesu evropského zákonodárství. Nicméně, mandát EO je kompetenčně omezen pouze na unijní správu, nikoliv na ty národní v členských státech. V př́ípadě, že Evropská komise předloží návrh, který se nějakým způsobem dotýká nebo má potenciál se dotknout práv občanů EU, každý národní ochránce práv má na základě dobrovolnosti právo předložit své expertízy a deklarovat své zkušenosti k nové přijímané záležitosti. ${ }^{32}$ Toto také bezpochyby přispívá k dodržování klíčových právních principů, na kterých je EU vybudována. Dochází však k i onomu posilování demokratické legitimity EU, a tím ke zvyšování legitimní důvěry v EU.

Doposud nebyla zodpovězena otázka, jaký je tedy faktický vztah mezi národními ochránci práv a Evropským ombudsmanem? Vymezení bývá kategorizováno do třech konceptů. První koncept lze označit za sebeurčení (self-determination), který operuje s premisou toho, že všichni aktéři mají stejné postavení, jsou si rovni. Tento koncept může převážně využívat jen diskurzu a hledání možného kompromisu bez semknutější vztahů, přičemž v určitých polemických a citlivých otázkách lze předpokládat obstrukce. Druhý jest koncept dobrovolné účasti (voluntary participation), který také respektuje stejné postavení participantů, ale zároveň očekává jejích užší sepjetí v rámci dobrovolného sdružení se. No a třetí je koncept podmíněné spolupráce (conditional cooperation), který se vyznačuje pevnými mantinely vůči činnosti Evropského ombudsmana, kterému není dovoleno vést vyšetřování na národní úrovni. ${ }^{33}$

Úřad evropského ochránce práv vykazuje vlastní organizační strukturu, což je zcela nezbytné k tomu, aby došlo k zajištění řádného řešení všech stížností vzhledem na jejich lingvistickou odlišnost více než dvaceti jazyků EU. Zcela na vrchu stojí evropský ombudsman a jeho kabinet, který mu poskytuje poradenství a podporu. Druhou složkou je generální sekretariát (secretary general), který odpovídá za celkové ř́zení Úřadu, ale i celkovou koordinaci provádění strategie evropského ombudsmana. Př́mo pod generální sekretariát spadá oddělení pro komunikaci (Communication Unit), personální - administrativní - rozpočtové oddělení (Personnel, Administrative and Budget Unit) a konečně ředitelství pro šetření (Directorate of Inquiries). Ředitelství pro šetření má pod sebou

31 PLÍVOVÁ, P. Český a evropský ombudsman jako ochránci před zakázanou diskriminací. Diplomová práce. Pardubice : Fakulta ekonomicko-správní UPCE, 2011, s. 20-21.

32 INGLESE, M. - BINDER, T. The European Ombudsman. In LEVI-FAUR, D. - WAARDEN, V. F. Democratic empowerment in the European Union. Cheltenham, UK - Northampton, MA - USA: Edward Elgar Publishing, 2018, s. 91.

33 INGLESE, M. - BINDER, T. The European Ombudsman. In LEVI-FAUR, D. - WAARDEN, V. F. Democratic empowerment in the European Union. Cheltenham, UK - Northampton, MA - USA: Edward Elgar Publishing, 2018, s. 91. 
vlastní oddělení vyřizování prrípadů (Case-handling Unit). Všechna oddělení jsou přitom na stejné úrovni, byt' dvě spadají pod generální sekretariát a jedno pod ředitelství pro šetření. ${ }^{34}$

Evropský ombudsman není novum na evropské institucionální scéně, nebot' existuje a vykonává svoji činnost již po dvacet šest let. Za tuto dlouhou dobu se již zapř́ičinil o mnohé úspěchy v rámci zajištění dobré veřejné správy EU, což lze deklarovat na základě výročních zpráv jeho činnosti, které jsou dostupné z oficiálních zdrojů. Osobně považujeme za velmi př́nosné zejména přijetí Evropského kodexu dobré správní praxe (angl. European Code of Good Administrative Behaviour), který sám však neoplývá právní závazností. ${ }^{35}$ Právní závaznost vyplývá z čl. 41 Listiny základních práv EU, který stanovuje právo na řádnou správu. ${ }^{36}$ Podstata práva na dobrou správu spočívá v očekávání určité kvality výkonu správní činnosti plně v souladu s dalšími parciálními principy. Listina jako taková se stala na základě ustanovení čl. 6 Smlouvy o Evropské unii součástí primárního práva EU (smluvní základny EU), což jí činí právně závaznou. ${ }^{37}$ Tento Kodex upravuje řadu principů dobré správy EU jako princip spravedlnosti (fairness), proporcionality, objektivity, zákonnosti (lawfulness), nestrannosti (impartiality), nezávislosti (independence), zdvořilosti (courtesy), nediskriminace (absence of discrimination), nezneužití moci (absence of abuse of power) či legitimního očekávání a konzistence rozhodování. ${ }^{38}$ Nutno podotknout, že spousta z oněch zmíněných principů se duplicitně překrývá s principy dobré veřejné správy předloženými Radou Evropy. Kodex tak úspěšně zohledňuje tradiční zásady evropského správního práva, které vyplývají z judikatury Soudního dvora EU, ale i Evropského soudu pro lidská práva. Vedle toho došlo v roce 2011 k zformulování tzv. Zásady veřejné služby (list of good practices), které slouží jako komplementarita dosavadních standardů a mající přinést jasný obraz toho, jak by se měly unijní instituce a orgány vypořádávat $\mathrm{s}$ nedostatky správní praxe. ${ }^{39}$ Vedle toho se Kodex stal i zdrojem interních institucionálních pravidel dobré správy jednotlivých subjektů EU (Kodex Evropské komise a jiné). ${ }^{40}$

34 Organizační diagram Úřadu evropského ochránce práv je dostupný na oficiálních webových stránkách Úřadu: https://www.ombudsman.europa.eu/cs/office/staff.

35 MOURE-PINO, A. M. The European Ombudsman in the framework of the European Union. In Revista Chilena de Derrecho, 2011, roč. 38, č. 3, s. 440 an.

36 Čl. 41 Listiny základních práv EU: „Každý má právo na to, aby jeho záležitosti byly orgány, institucemi a jinými subjekty Unie ř rěeny nestranně, spravedlivě a v přiměrené lhưtě.“

37 Čl. 6 odst. 1 SEU: „Unie uznává práva, svobody a zásady obsažené v Listině základnich práv Evropské unie ze dne 7. prosince 2000, ve zněni upraveném dne 12. prosince 2007 ve Štrasburku, jež má stejnou právní sílu jako Smlouvy.“

38 Princip legitimního očekávání má velmi blízko i k principu právní jistoty, vedle toho však stojí za zmínku i princip ,patere legem quam ipse fecist" neboli v překladu princip dobré víry (principle of a good faith).

39 Emily O'Reilly: ,White the EU institutions generally have good anti-harassment policies, my report shows that more can and must be done to bring them into line with the legitimate expectations of a post.“ BANKS, M. EU Ombudsman creates 'good practices' list to combat harassment. In The Parliament Magazine [online]. Zveřejněno dne: 02. 01. 2019. Dostupné z: https://www.theparliamentmagazine. eu/news/article/eu-ombudsman-creates-good-practices-list-to-combat-harassment.

40 MENDES, J. Good Administration in EU Law and the European Code of Good Administration Behaviour. Working Paper. Florencie : European University Institute - EUI LAW, 2009/09, s. 11. 


\section{Historické reálie a důvody zrodu instituce evropského ombudsmana}

Historie konceptu ombudsmana je letitá a bohatá. Není k údivu, že tento koncept se zrodil ve Skandinávských zemích. Vůbec jednu z prvních zmínek lze datovat k roku 1713, kdy byl ve Švédsku zř́żen úřad Královského Nejvyššího Ombudsmana (Kings Highest Ombudsman), který byl pověřen úkolem dohledu nad dodržováním zákonů a ostatních právních předpisů při plnění povinností orgánů státního aparátu. ${ }^{41}$ Jinými slovy měl za úkol dohlížet a hájit zájmy lidu v monarchii. ${ }^{42}$ Další z řady proměn přišla v roce 1953 z Dánska, kde byl zaveden úrad reprezentanta občanského prvku na vládnutí, respektive jeho posílení, tehdejší kancelář byla označena jako „Danish Ombudsman Office“. Primárním úkolem tohoto úřadu bylo zastupovat oprávněné zájmy občanů při kolizi se státní mocí. Na základě těchto historických reálií není k podivu, že se vůbec prvním evropským ombudsmanem stal Jacob Söderman původem z Finska. Nicméně, zrod a proliferace konceptu ombudsmanství bývá připisována tendencím o navyšování správné a právní regulativnosti denních záležitostí občanů, kteří se musejí potýkat se složitým a značně zatěžujícím administrativním aparátem státu. Administrativní správa státu bývá prostoupena nežádoucími jevy byrokratismu a přepjatého formalismu. ${ }^{43}$ Přičemž, obecně je státní správě vyčítána nedostatečná kontrola a zanedbávaný dohled. ${ }^{44}$ Koncept ombudsmanství se stal natolik populární záležitostí, že se začal nekontrolovatelně rozmáhat např́ič světovými státnostmi. V této souvislosti se někdy hovoří též o „ombudsmanii‘, která byla vyvolána tužbou zmírnění vážných nedostatků rozmáhající se administrativy a snahou o vyvážení její anonymizace prostřednictvím personalizace správní kontroly. ${ }^{45}$

Zř́zzení Úřadu evropského veřejného ochránce práv bylo podmíněno mnohými faktickými důvody a potřebami, které se nesly v souvislosti s vývojem a modernizací evropských vztahů. Institucionální struktura EU se kvantitativně rozšiřovala o další a další unijní orgány, přičemž si tento nárůst počtu unijních orgánů veřejné správy žádal i posílení kontrolních mechanismů. A fortiori tím vznikala potřeba zmírňovat možné

41 PLÍVOVÁ, P. Český a evropský ombudsman jako ochránci pred zakázanou diskriminací. Diplomová práce. Pardubice : Fakulta ekonomicko-správní UPCE, 2011, s. 11.

42 INGLESE, M. - BINDER, T. The European Ombudsman. In LEVI-FAUR, D. - WAARDEN, V. F. Democratic empowerment in the European Union. Cheltenham, UK - Northampton, MA - USA : Edward Elgar Publishing, 2018, s. 86.

43 Byrokracie je pojem vzešlý od Maxe Webbera, který jej definoval v rámci své teorie byrokracie tak, že definoval několik charakteristických znaků byrokracie. Mezi tyto znaky řadíme 1 . hierarchická struktura, 2. formální pravidla a regulativy, 3. personální kvalifikovaná volba, 4. formalizované sociální vztahy, 5. stabilnost odměn, 6. separace vlastnictví od funkce, 7. regulérní kariéra, 8. kvalifikované funkce a pracovní pozice. SERPA, S., FERREIRA, C. M. The Concept of Bureaucracy by Max Webber. In International Journal of Social Science Studies, 2019, roč. 7, č. 2, s. 14.

44 INGLESE, M. - BINDER, T. The European Ombudsman. In LEVI-FAUR, D. - WAARDEN, V. F. Democratic empowerment in the European Union. Cheltenham, UK - Northampton, MA - USA: Edward Elgar Publishing, 2018, s. 86-87.

45 MOURE-PINO, A. M. The European Ombudsman in the framework of the European Union. In Revista Chilena de Derrecho, 2011, roč. 38, č. 3, s. 427. 
negativní dopady činnosti byrokratického aparátu, tedy jednotlivých výkonných složek EU. Konečně tak šlo především o odstraňování nedostatků a pochybení unijní veřejné správy a její činnosti. Instituce evropského veřejného ochránce práv pak zajisté vedla i k posílení legitimnosti a zákonnosti veřejné správy EU. Institut ombudsmanství většinou oplývá demokratickým étosem, což podporuje jeho důvěryhodnost a uznání jeho autority. Př́nos se týká i stanovení pevně etablovaných standardů činnosti veřejné správy. ${ }^{46}$

Vůbec první návrh na zřízení Úřadu evropského ombudsmana vzešel roku 1979 od Výboru pro právní záležitosti při Evropském parlamentu (angl. Legal Affairs Committee of the European Parliament). Tento návrh se však setkal s negativní kritikou a odmítavým postojem především Evropské komise (dále jen „EK“). Po téměř patnácti letech bylo dne 3. března 1994 na základě Maastrichtské smlouvy (1992) přijato formální zřízení evropského ombudsmana k odkrývání nesprávného úředního postupu v aktivitách unijních institucí a orgánů, ale také k tvorbě konstitutivních doporučení vedoucích k odstranění či eliminaci takových nežádoucích aktivit. Celý stav byl projevem objektivní potřeby zavedení instituce, která bude aktivně posilovat kontrolní mechanismy unijních institucí a dohlížet nad harmonizací acquis communautaire, tedy unijním právním pořádkem. ${ }^{47}$ A priori se projevovala i touha po snižování vážných nedemokratických vad evropského vládnutí a snaha k předejití odcizení se skeptické veřejnosti od anonymizované unijní administrativy. Těmito kroky se mělo dojít zlepšení vztahů mezi euroobčany a euro-administrativou. ${ }^{48}$

Ochrana práv osob v EU nabývala a neustále i nabývá na svém významu. Jednou z možných cest bylo i zajištění řádného a správného fungování úřednického aparátu EU tak, aby se minimalizovaly byrokratické neduhy jeho činnosti. V souvislosti s tím však můžeme hovořit o iniciativě, které předcházela a posléze i šla ruku v ruce s EU. Koncept dobré veřejné správy, někdy označovaný jako tzv. kultura správní služby, ${ }^{49}$ se totiž nevyvíjel pouze $\mathrm{v}$ souvislosti s činností EU, ale právě s mezinárodním zájmem na zajištění určité úrovně (standardů) činnosti správní orgánů jednotlivých států. Flagrantní snahu v tomto směru vyvíjela Rada Evropy, která v minulosti představila několik principů dobré veřejné správy. Principy dobré veřejné správy pak tvoří součást principů evropského správního práva. ${ }^{50}$ Principy dobré veřejné správy jsou komplexně upraveny v doporučení $\mathrm{CM} / \operatorname{Rec}(2007) 7$ Výboru ministrů o dobré veřejné správě. ${ }^{51}$

46 PLÍVOVÁ, P. Český a evropský ombudsman jako ochránci před zakázanou diskriminací. Diplomová práce. Pardubice : Fakulta ekonomicko-správní UPCE, 2011, s. 11-12.

47 SKÁLA, J. Ombudsman v Evropě a Evropský ombudsman. In Právník, 1994, roč. 133, č. 9, s. 820-824.

48 INGLESE, M. - BINDER, T. The European Ombudsman. In LEVI-FAUR, D. - WAARDEN, V. F. Democratic empowerment in the European Union. Cheltenham, UK - Northampton, MA - USA: Edward Elgar Publishing, 2018, s. 88.

49 MENDES, J. Good Administration in EU Law and the European Code of Good Administration Behaviour. Working Paper. Florencie : European University Institute - EUI LAW, 2009/09, s. 10.

50 KOŠIČIAROVÁ, S. Princípy dobrej verejnej správy a Rada Európy. Bratislava : Iura Edition, 2012, s. 11.

51 Jednotlivými principy dobré veřejné správy jsou zákonnost, rovnost a zákaz diskriminace, nestrannost a objektivita, proporcionalita, právní jistota, přiměřenost časové lhůty, transparentnost, participace a respekt soukromí. 
Toto doporučení obsahuje i návrh na vytvoření Kodexu dobré veřejné správy, který je silně motivován Evropským kodexem dobré správní praxe ze dne 2001 od Evropského parlamentu. ${ }^{52}$ Vedle toho se činnosti EO dotýká i rozhodovací činnost ESLP, což vychází z toho, že EO může své úkony opřít o ustanovení Evropské úmluvy o ochraně lidských práv, a to v př́padě porušení lidských práv. ESLP ve vztahu k činnosti EO sdílí poselství podpory v dláždění cesty k ochraně lidských práv. ${ }^{53}$ Tomu svědčí i mnohá judikatura ESLP, která se dotýká činnosti Evropského ombudsmana. ${ }^{54}$

\section{Komplikace ideálního fungování instituce evropského ochránce práv}

Podle našeho názoru může být jednou z nejpodstatnějších překážek problém (ne) dostupnosti. Je třeba tyto instituce (Evropského ombudsmana) učinit dostupnější široké veřejnosti. Objektivní znaky přístupu euro-občanů k EO jsou bezpochyby jeho flexibilita a bezplatnost (za podání stížnosti se naplatí žádný poplatek). Někdy k nim bývá přiřazován i znak rychlosti, o kterém by se však dalo polemizovat, proto jej označíme spíše za subjektivní znak. Celá diskuze se však týká spíše otázky úrovně celkové dostupnosti služeb EO. Někteří však spatřují širší přesah problému, nebot' se opírají o obecný argument absence principu prŕístupnosti veřejné správy. ${ }^{55}$ Menší nejasností $\mathrm{k}$ tomu zůstává jazyková bariéra $v$ prístupu a jednání s celou strukturou Úřadu evropského ombudsmana, obecněji s unijními institucemi vůbec. Nicméně, nutno podotknout na skutečnost, že Úřad disponuje poměrně rozsáhlým multinárodním personálním aparátem zajišt'ujícím jeho činnost. Úřad je tak schopný reagovat na podněty více než dvaceti jazyky EU tak, aby byl co možná nejdostupnější všem euro-občanům. Za jednoznačný nedostatek můžeme spatřovat nízkou úroveň povědomí (awareness) o existenci a činnosti EO, což pro něj na druhou stranu představuje další výzvu k řešení. ${ }^{56}$

Zde narážíme na problém nedostatečné transparentnosti, nebot' aby se lidé mohli na tuto instituci obracet, musejí o ní především vědět. Jak se mohou obracet se svými problémy a stížnosti na něco, o čem nevědí, že vůbec existuje? Transparentnost je jednou z klíčových oblastí činnosti Evropského ochránce práv, kterou se snaží o zajištění lepšího a snazšího př́ístupu široké veřejnosti k informacím a dokumentům týkajících se činnosti unijních subjektů, ale i činnosti Úřadu evropského ombudsmana. Úsilí o větší míru transparentnosti je možné poměrně hojně deklarovat na základě kazuistiky. ${ }^{57}$ Evro-

52 KOŠIČIAROVÁ, S. Princípy dobrej verejnej správy a Rada Európy. Bratislava : Iura Edition, 2012, s. 25.

53 LAFFRANQUE, J. The Ombudsman in the Eyes of the European Court of Human Rights. In Juridica International, 29/2020, s. 107.

54 Rozsudek ESLP ze dne 27. 11. 2007 Ap. No. 20477/05 ve věci Tillack v. Belgium, rozsudek ESLP ze dne 03. 10. 2014 Ap. No. 12738/10 ve věci Jeunesse v. The Netherlands, rozsudek ESLP ze dne 21. 06. 2016 ve věci Ap. No. 76136/12 ve věci Ramadan v. Malta.

55 LIBERDOVÁ, E. Právo na dobrou správu jako princip veřejné správy v EU. In epravo.cz [online]. Zveřejněno dne: 21. 07. 2015. Dostupné z: https://www.epravo.cz/top/clanky/pravona-dobrou-spravu-jako-princip-verejne-spravy-v-eu-98220.html.

56 MOURE-PINO, A. M. The European Ombudsman in the framework of the European Union. In Revista Chilena de Derrecho, 2011, roč. 38, č. 3, s. 425-426.

57 VOGIATZIS, N. The European Ombudsman and Good Administration in the European Union. 
pský ombudsman kupř́íkladu v minulosti oslovil Evropskou radu, aby zvážila možnost zveřejňování informací z jejich setkání v rámci Registru transparentnosti EU. ${ }^{58}$ Evropský ombudsman k tomu však uvádí, že sám neoplývá naivitou v tom směru, že by byl přesvědčen o náklonosti Evropské komise a Rady k rapidnímu zvýšení transparentnosti. Nepřímý problém může být nadále shledán i ve ztrátě důvěry v EU a její instituce a orgány, což úzce souvisí se záležitostí demokratického deficitu EU. V návaznosti na statistická data sesbíraná v rámci databáze Eurostat př́mo vyplývá závěr, že důvěra v unijní instituce neustále klesá. ${ }^{59}$ Rozšiřování obecného povědomí o existenci EO jde ruku v ruce i s rozšiřováním povědomí o kvalitativním i kvantitativním rozrůstání katalogu lidských práv v EU. ${ }^{60}$

Evropský ombudsman nemá explicitně omezený rozsah svojí působnosti, z čehož vyplývá, že se jeho kontrolní činnost může dotýkat všech unijních institucí a orgánů. In concreto se může jednat o Evropský parlament, Radu EU, Evropskou komisi, Soudního dvora EU (vyjma soudních rozhodovacích pravomocí) a mnohé další instituce a orgány EU. Jeho působnost se vztahuje i na OLAF či Europol, což by nebylo nic zarážejícího. ${ }^{61}$ Na zamyšlení ovšem zůstává působnost vůči nedávno zř́zenému Úřadu evropského veřejného žalobce (dále „ÚEVŽ). Podle našeho přesvědčení se jeho působnost bude řídit obdobně jako je tomu v př́ípadě Soudního dvora EU. Evropský ombudsman tak bude sice oprávněn kontrolovat činnost ÚEVŽ, ale s vyloučením jeho vyšetřovacích pravomocí a pravomocí k zahájení trestního stíhání. Toto řešení se nám jeví jako přípustné, nebot' ani v národních sférách nemohou veřejní ochránci práv intervenovat do výkonu trestních jurisdikcí států. V prŕípadě, že by tomu bylo jinak, tak by docházelo ke střetu jednotlivých mocí, což by bylo právně zcela nepřijatelné. Evropský ombudsman však také v jisté rovině participuje na ochraně finančních zájmů EU. ${ }^{62}$

Za další komplikaci může být považován nedostatek př́mých pravomocí ke zjednání nápravy či odstranění zjišsěných nedostatků, tedy v absenci právně závazných instrumentů. Obecně můžeme hovořit o zdánlivé slabosti Úřadu evropského ombudsmana. Tato skutečnost však vyplývá z vlastní podstaty ombudsmanství, nebot to nemá být nadáno vlastními výkonnými pravomocemi, ale pouze obtěžkáno jistou mírou důvěryhodnosti, respektu a vážnosti, které mu zajišt'ují dostatečnou iniciativu k přijetí adekvátních reakcí

London : Palgrave Macmillan UK, 2018, s. 145 an.

58 RADOSAVLJEVIC, Z. EU Ombudsman asks Council to join transparency register. In Euractiv [online]. Zveřejněno dne: 18. 12. 2017. Dostupné z: https:/www.euractiv.com/section/politics/ news/eu-ombudsman-asks-council-to-join-transparency-register/.

59 MORGAN, S. Loss of trust in EU has social and economic consequences. In Euractiv [online]. Zveřejněno dne: 26. 05. 2017 (novelizováno 29. 05. 2017). Dostupné z: <https://www.euractiv. $\mathrm{com} / \mathrm{section} /$ politics/news/loss-of-trust-in-eu-has-social-and-economic-consequences/>.

60 TRIDIMAS, G. - TRIDIMAS, T. Public awareness of EU rights and the functions of the European Ombudsman: some unpleasant findings. In HOFMANN, H. C. H., ZILLER, J. Accountability in the EU: the role of the European Ombudsman. Cheltenham : Edward Elgar Publishing, 2017, s. 74-93.

61 PLÍVOVÁ, P. Český a evropský ombudsman jako ochránci před zakázanou diskriminací. Diplomová práce. Pardubice : Fakulta ekonomicko-správní UPCE, 2011, s. 16.

62 PÁSTOROVÁ, M. Právní úprava pravomocí veřejného ochránce práv v ČR. Diplomová práce. Praha : Právnická fakulta UK, 2019, s. 51. 
v kooperaci s prímo kompetentními orgány, které takovou mocí disponují. Tento stav si lze demonstrovat na skutečnosti, že Evropský ombudsman není nadán legislativní iniciativou, tedy nemůže př́ímo podávat návrhy na změnu unijní legislativy. ${ }^{63}$ Může tak učinit pouze nepř́mo, zprostředkovaně za využití právně nezávazných nástrojů, které předkládá př́slušným vrcholným institucím, př́íkladně Evropskému parlamentu. Zároveň však potřebuje i vhodnou oporu a ochranu Evropského parlamentu. ${ }^{64}$ Těmto institucím je však ponechán dispoziční prostor $\mathrm{k}$ tomu, aby s danými závěry či podněty volně naložily podle své vlastního uvážení a rozhodnutí. Relativní slabost jeho postavení však může vykazovat výhody i nevýhody. Výhodami může být volnější pole působnosti v zaobírání se širokým spektrem unijních záležitostí. Zároveň však i skutečnost toho, že když nemůže závazně nařizovat povinnosti, tak se těší větši míře ochoty k navozování dialogu k nalezení schůdných řešení vzniklých nedostatků či pochybení. ${ }^{65}$

\section{Závěr}

Dnes je Úřad evropského ombudsmana vnímán jako inkarnace efektivní účelné instituce sui generis a zároveň jako ideální reprezentant a propagátor principů rule of law, dobré správy a ochrany lidských práv a svobod. Evropský ombudsman tak př́mo poskytuje ochranu lidských práv a vyvozuje odpovědnost veřejné správy v př́padě jejího pochybení. Plnění nejen tohoto poslání potom přispívá $\mathrm{k}$ tlumení demokratického deficitu EU, posilování vzájemné důvěry mezi členskými státy, garantování dostatečné transparentnosti a $\mathrm{k}$ jiným axiologickým předsevzetím. ${ }^{66}$ Obecně lze pravit, že Úřad plní funkci vnější doplňkové ochrany vǔči činnosti veřejné správy EU. Úřad evropského ochránce práv má směřovat k dosáhnutí nejvyššího možného standardu správních postupů unijních subjektů ku prospěchu občanů EU. Takové cíle jsou předpokládány i v rámci nové strategie Úřadu, která je nazvaná „Towards $2024^{\prime \prime}$, která plně koresponduje s hlavní politickou náplní EU. Do současnosti přitom přetrvávají, ale i přibývají další cíle, kterých se snaží Ứrad evropského veřejného ochránce práv dosáhnout. Mezi nimi může identifikovat zvýšení oné transparentnosti EU, posílení prrístupu $\mathrm{k}$ informacím, neustálá podpora dialogu mezi unijními institucemi a orgány, prosazování principů dobré veřejné správy v EU a konečně i obecná podpora a zkvalitňování unijní administrativy. ${ }^{67}$

Úřad evropského ombudsmana představuje nezávislý orgán potencionálně schopný vyvíjet nemalý vliv na legislativní a justiční větve EU, z čehož mohou, a především

63 PÁSTOROVÁ, M. Právni úprava pravomocí veřejného ochránce právv ČR. Diplomová práce. Praha : Právnická fakulta UK, 2019, s. 52.

64 GAMMELTOFT-HANSEN, H. Protecting the institution of European ombudsman. In Politico [online]. Zveřejněno dne: 26. 06. 2013. Dostupné z: https://www.politico.eu/article/protectingthe-institution-of-european-ombudsman/.

65 POSPÍŠILOVÁ, A. Evropský veřejný ochránce práv. Diplomová práce. Olomouc : Právnická fakulta UP, 2011, s. 37.

66 VOGIATZIS, N. The European Ombudsman and Good Administration in the European Union. London : Palgrave Macmillan UK, 2018, s. 57 an.

67 POSPÍŠILOVÁ, A. Evropský veřejný ochránce práv. Diplomová práce. Olomouc : Právnická fakulta UP, 2011, s. 36. 
i mají profitovat občané EU. Ti jsou přitom nadáni aktivním právem obracet se na evropského ochránce práv v souvislosti s nesprávným úředním postupem institucí a orgánů EU, který se jejich zájmů dotýká. Evropský ombudsman posléze prověřuje všechny stížnosti na činnost unijních institucí či orgánů a vyvozuje z nich náležité závěry, které by měly vést $\mathrm{k}$ nápravě vadného stavu. ${ }^{68}$ Urăad tak charakterizujeme jako nezávislý a nestranný subjekt, který povolává k odpovědnosti jiné subjekty EU a tím prosazuje řádnou správu unijní agendy. EO svojí činností zlepšuje (humanizuje) vztahy mezi euro-občany a institucemi a orgány EU. Otázkou už jen zůstává, v jaké skutečné míre? Evropský ombudsman je tak slovy E. O’Reilly považován za reflektor vynesení kauzalit nesprávných úředních postupů na světlo. ${ }^{69}$ Naopak podle vyjádření Evropského parlamentu práce EO posiluje etiku a odpovědnost institucí EU čili je hodnocena jako vysoce příznivá a pozitivní. Role EO jako mediátora nesprávného úředního postupu se jeví jako absolutně nezbytná v rámci normativně-funkčního a institucionálního zázemí EU. EO je v pozici nezávislého kritika kvality unijní správy, přičemž má potenciál pozitivně stimulovat její rozvoj a zkvalitnění směrem k přiblížení se občanům EU.

Veřejná správa je dnes vnímána jako služba veřejnosti, v čemž se zrcadlí i očekávání kvalitního výkonu správní činnosti. Konec konců princip služby veřejnosti je obsažen i v českém správním řádu, který tuto skutečnost petrifikuje. ${ }^{70}$ Principy dobré veřejné správy přispívají k realizaci práva na dobrou správu (good governance). Prosazování principů dobré veřejné správy v praxi má zabezpečit efektivnost výkonu veřejné správy ve smyslu služby veřejnosti tak, aby nedocházelo k nezákonnému a nedůvodnému zasahování do subjektivních práv občanů. ${ }^{71}$ Právo na dobrou správu se přitom dnes řadí mezi základní občanská práva, nebot' nachází své formální zakotvení v řadě právně závazných dokumentů a předpisů. A priori však platí, že dobrá správa závisí na lidském faktoru a kvalitě jeho řízení a činnosti. Pokud selže lidských faktor, tak veřejná správa následuje jeho osud. Bez ohledu na faktický stav administrativy platí, že sdílení a uplatňování principů dobré veřejné správy mezi členskými státy EU přispívá a posiluje evropský správní prostor. ${ }^{72} \mathrm{~V}$ dnešní době národní veřejná správa

68 GRASSO, G. The European Ombudsman as an Insurmountable Roadblock? The New Right to Request the European Parliament to de-Register European Political Parties. In VerfBlog [online]. Zveřejněno dne: 15. 10. 2019. Dostupné z: https://verfassungsblog.de/the-europeanombudsman-as-an-insurmountable-roadblock/.

69 Emily O'Reilly: „European Ombudsman bringing instances of maladministration to light by adopting a case-by-case approach and increasing the number of own-initiative inquiries."BANKS, M. EU Ombudsman creates 'good practices' list to combat harassment. In The Parliament Magazine [online]. Zveřejněno dne: 02. 01. 2019. Dostupné z: https://www.theparliamentmagazine.eu/news/ article/eu-ombudsman-creates-good-practices-list-to-combat-harassment.

$70 \S 4$ odst. 1 zákona č. 500/2004 Sb., správní řád: „Veřejná správa je službou veřejnosti. Každý, kdo plní úkoly vyplývajicí z působnosti správního orgánu, má povinnost se k dotčeným osobám chovat zdvořile a podle možností jim vycházet vstřic."

71 KOŠIČIAROVÁ, S. Princípy dobrej verejnej správy a Rada Európy. Bratislava : Iura Edition, 2012, s. 12.

72 HARDEN, I. The European Ombudsman's role in promoting good governance. In HOFMANN, H. C. H. - ZILLER, J. Accountability in the EU: the role of the European Ombudsman. Cheltenham : Edward Elgar Publishing, 2017, s. 198-216. 
vykonává správní činnost (plní správní úkoly) ve stínu evropské integrace, přičemž správní orgány disponují organizační a procesní autonomií jako nepřímý vykonavatelé evropského práva. ${ }^{73}$

\section{Literatura:}

- BANKS, M. 2019. EU Ombudsman creates 'good practices' list to combat harassment. In The Parliament Magazine [online]. Zveřejněno dne: 02. 01. 2019. Dostupné z: https://www.theparliamentmagazine.eu/news/article/eu-ombudsmancreates-good-practices-list-to-combat-harassment.

- BATALLI, M. 2015. Role of Ombudsman Institution Over the Administration. In Academic Journal of Business, Administration, Law and Social Sciences, 2015, roč. 1, č. 3, s. 232-240. ISSN 2410-3918.

- CRAIG, P. 2018. EU administrative law. Oxford : Oxford University Press, 2018. 836 s. ISBN 978-0-19-883164-8.

- GAMMELTOFT-HANSEN, H. 2013. Protecting the institution of European ombudsman. In Politico [online]. Zveřejněno dne: 26. 06. 2013. Dostupné z: https:// www.politico.eu/article/protecting-the-institution-of-european-ombudsman/.

- GOBBI, M. The European Ombudsman: a modern Defensor Civitatis of EU citizens. In Academia [online]. Dostupné z: https://www.academia.edu/2246611/ The_European_Ombudsman_a_modern_Defensor_Civitatis_of_EU_citizens_M Gobbi_en.

- GRASSO, G. 2019. The European Ombudsman as an Insurmountable Roadblock? The New Right to Request the European Parliament to de-Register European Political Parties. In VerfBlog [online]. Zveřejněno dne: 15. 10. 2019. Dostupné z: https://verfassungsblog.de/the-european-ombudsman-as-an-insurmountableroadblock/.

- HOFMANN, H. C. H. - ZILLER, J. 2017. Accountability in the EU: the role of the European Ombudsman. Cheltenham : Edward Elgar Publishing, 2017. 285 s. ISBN 978-1-78536-730-4.

- KOŠIČIAROVÁ, S. 2012. Princípy dobrej verejnej správy a Rada Európy. Bratislava : Iura Edition, 2012. 556 s. ISBN 978-80-8078-519-2.

- KUCSKO-STANDLMAYER, G. (ed.) 2008. European Ombudsman-Institutions. Vienna : Springer, 2008. 584 s. ISBN 978-3-211-72882-6 (ebook).

- LAFFRANQUE, J. 2020. The Ombudsman in the Eyes of the European Court of Human Rights. In Juridica International, 29/2020, s. 95-107. ISSN 1406-1082.

- LEVI-FAUR, D. - WAARDEN, V. F. 2018. Democratic empowerment in the European Union. Cheltenham, UK - Northampton, MA - USA : Edward Elgar Publishing, 2018. 320 s. ISBN 978-1-78811-355-7.

- LIBERDOVÁ, E. 2015. Právo na dobrou správu jako princip veřejné správy v EU. In epravo.cz [online]. Zveřejněno dne: 21. 07. 2015. Dostupné z: https://www.epravo.

73 LIBERDOVÁ, E. Právo na dobrou správu jako princip veřejné správy v EU. In epravo.cz [online]. Zveřejněno dne: 21. 07. 2015. Dostupné z: https://www.epravo.cz/top/clanky/pravona-dobrou-spravu-jako-princip-verejne-spravy-v-eu-98220.html. 
cz/top/clanky/pravo-na-dobrou-spravu-jako-princip-verejne-spravy-v-eu-98220. html.

- MENDES, J. 2009. Good Administration in EU Law and the European Code of Good Administration Behaviour. Working Paper. Florencie : European University Institute - EUI LAW, 2009/09, 13 s. ISSN 1725-6739.

- MOURE-PINO, A. M. 2011. The European Ombudsman in the framework of the European Union. In Revista Chilena de Derrecho, 2011, roč. 38, č. 3, s. 421-455. ISSN 0716-0747.

- MORGAN, S. 2017. Loss of trust in EU has social and economic consequences. In Euractiv [online]. Zveřejněno dne: 26. 05.2017 (novelizováno 29. 05. 2017). Dostupné z: <https://www.euractiv.com/section/politics/news/loss-of-trust-in-euhas-social-and-economic-consequences/>.

- MORRISSEY, C. 2021. EU accused of 'maladministration' on Mercosur deal by Ombudsman. In Irish Farmers Journal [online]. Zveřejněno dne: 20. 03. 2021. Dostupné z: https://www.farmersjournal.ie/eu-accused-of-maladministration-onmercosur-deal-by-ombudsman-610282.

- PÁSTOROVÁ, M. 2019. Právni úprava pravomocí veřejného ochránce práv v ČR. Diplomová práce. Praha : Právnická fakulta UK, 2019. 57 s.

- PLÍVOVÁ, P. 2011. Český a evropský ombudsman jako ochránci před zakázanou diskriminací. Diplomová práce. Pardubice : Fakulta ekonomicko-správní UPCE, 2011. $76 \mathrm{~s}$.

- POSPÍŠILOVÁ, A. 2011. Evropský veřejný ochránce práv. Diplomová práce. Olomouc : Právnická fakulta UP, 2011. 64 s.

- RADOSAVLJEVIC, Z. 2017. EU Ombudsman asks Council to join transparency register. In Euractiv [online]. Zveřejněno dne: 18. 12. 2017. Dostupné z: https:// www.euractiv.com/section/politics/news/eu-ombudsman-asks-council-to-jointransparency-register/.

- SERPA, S. - FERREIRA, C. M. 2019. The Concept of Bureaucracy by Max Webber. In International Journal of Social Science Studies, 2019, roč. 7, č. 2, s. 12-18. ISSN 2324-8041 (online).

- SIMAN, M. - SLAŠŤAN, M. Právo Európskej únie. Bratislava : EUROIURIS, 2012, 1232 s. ISBN 978-80-89406-12-8.

- SKÁLA, J. 1994. Ombudsman v Evropě a Evropský ombudsman. In Právník, 1994, roč. 133, č. 9, s. 820-836. ISSN 0231-6625.

- ŠABATOVÁ, A. - KŘEČEK, S. a kol. 2017. Občanství Evropské unie. Brno : Kancelář veřejného ochránce práv, 2017. 136 s. ISBN 978-80-7552-802-5.

- TOMÁS̆EK, M. a kol. 2013. Právo Evropské unie. Praha : Leges, 2013. 496 s. ISBN 978-80-87576-53-3.

- VOGIATZIS, N. 2018. The European Ombudsman and Good Administration in the European Union. London : Palgrave Macmillan UK, 2018. 322 s. ISBN 9781-137-57395-7 (ebook).

\section{Právní předpisy a jiné dokumenty}

- Evropský kodex dobré správní praxe.

- Listina základních práv EU (2012/C 326/02). 
- Rozhodnutí Evropského parlamentu o pravidlech a obecných podmínkách pro výkon funkce veřejného ochránce práv ze dne 09. 03. 1994, ve znění př́slušných změn.

- Rozsudek ESLP ze dne 27. 11. 2007 Ap. No. 20477/05 ve věci Tillack v. Belgium.

- Rozsudek ESLP ze dne 03. 10. 2014 Ap. No. 12738/10 ve věci Jeunesse v. The Netherlands.

- Rozsudek ESLP ze dne 21. 06. 2016 ve věci Ap. No. 76136/12 ve věci Ramadan v. Malta.

- Smlouva o Evropské unii.

- Smlouva o fungování Evropské unie.

- Zákon č. 500/2004 Sb., správní řád, ve znění pozdějších předpisů.

\section{Summary: The European Ombudsman}

The topic of this contribution deals with the problematics of the European Ombudsman. The institution of European Ombudsman represents an effective contol mechanism of the EU administration, especially towards a detection and correction of maladministration. The contribution is devided into three main sections. The first part is dedicated to the basic characteristics of the European Ombudsman. The second section is focused on the historical facts and reasons of establishment of the European Ombudsman. The third part presents the current complications and opportunities of the European Ombusman. The aim of this contribution is to remind the European Ombudsman in the facts and to show its possible new challenges in accordance with the development of the EU. One of the main benefits can be seen in reduction of democratic deficit of the EU and protection of human rights toweards the european citizens.

JUDr. Bc. Štěpán Kořínek Univerzita Karlova v Praze Právnická fakulta nám. Curieových 901/7, 11640 Praha 1 Česká republika e-mail: skorinek@seznam.cz,gmkorinek@gmail.com 